\title{
REE analysis of fluorite from the Illinois-Kentucky Fluorspar District
}

\author{
J.N. BERGBOWER ${ }^{1}$, C.DIETSCH $^{1 *}{ }_{\text {RAKOVAN }}^{3}{ }^{3}$, J.W. SINGER ${ }^{2}$, J. \\ ${ }^{1}$ University of Cincinnati, Cincinnati, OH 45221-0013 USA \\ (bergbojn@mail.uc.edu; *correspondence: \\ dietscc@ucmail.uc.edu) \\ ${ }^{2}$ Rensselaer Polytechnic Institute, Troy, NY 12180 USA \\ (singej2@rpi.edu) \\ ${ }^{3}$ Miami University, Oxford, OH 45056 \\ (rakovajf@miamioh.edu)
}

The Illinois-Kentucky Fluorspar District (IKFD) located in the northern New Madrid Rift Zone is a fluoritic MVT deposit with minor $\mathrm{Pb}-\mathrm{Zn}$ mineralization. In the district are Permian ultramafic and lamprophyre dikes, pipes, and diatremes; Hicks Dome (HD), a crypto-explosion structure formed by the release of magmatic volatiles from a carbonatite complex with elevated REE content; and the Coefield Intrusive Complex, a magnetic high with REEbearing perovskite alnöite[1]. Decreasing fluid inclusion temperatures and changes in fluorite chemistry from HD to the fringes of the district can be interpreted as magmatic input from HD into a regional MVT system, and previous studies support a model for magmatic gases lowering fluid $\mathrm{pH}$, supplying fluorine, and brecciating host rocks. We analysed the REE and selected trace element chemistry of 270 fluorite grains from 32 locations across the IKFD using LA-ICP-MS, including early- and later-forming fluorite derived from the paragenetic sequence. REE concentrations are uniformly low, typically $10^{-2-0} \mathrm{ppm}$. There are two typical patterns of REE.

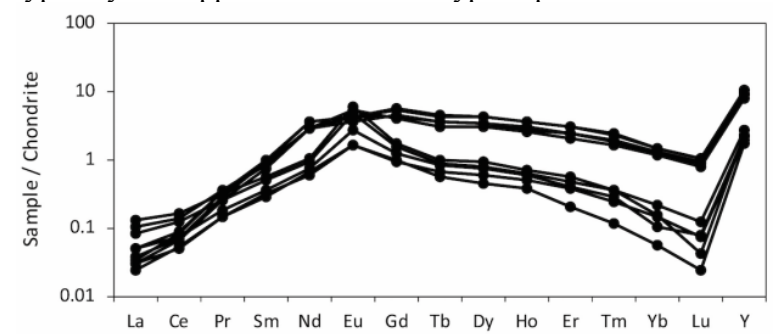

Figure 1: REE patterns of early (upper patterns) and later (lower patterns) fluorite from the Hill Mine, Illinois. Early fluorite can have a small positive Gd anomaly.

Fluorite REE patterns are not similar to fluorite from a mineralized fracture within the ultramafic Sparks Hill diatreme nor to whole rock patterns of intrusive rocks within the IKFD. Our data suggest little input of magmatic fluid into the regional MVT system.

[1] Anderson (2019) KY Geol Survey Report of Investigations 8 doi.org/10.13023/kgs.ri08.13. 